\title{
SELECTION OF THE OPTIMAL REAL ESTATE INVESTMENT PROJECT BASING ON MULTIPLE CRITERIA EVALUATION USING STOCHASTIC DIMENSIONS
}

\author{
Romualdas Ginevičius $^{1}$, Viktoras Zubrecovas ${ }^{2}$ \\ Vilnius Gediminas Technical University, Saulètekio al. 11, LT-10223 Vilnius, Lithuania \\ E-mails:1'romualdas.ginevicius@adm.vgtu.lt; ${ }^{2}$ ntbiuras@yahoo.com \\ Received 23 June 2009; accepted 24 August 2009
}

\begin{abstract}
As investment in real estate has great influence on regional economics development it is important to evaluate real estate investment processes as a whole. For this purpose the model of real estate projects' efficiency evaluation was developed and presented in this article. The proposed model is designed for alternative projects, variants selection, investment resources allocation as well as real estate value maintenance and enhancement problems solution. The model of real estate projects' efficiency evaluation covers all the investment decision-making cycle, the hierarchically-structured projects' evaluation criteria system, risk evaluation basing on stochastic dimensions as well as the mathematical methods adaptation for multiple criteria evaluation problems solution, risk assessment and adjusted mathematical methods is presented in this issue.
\end{abstract}

Keywords: real estate projects, evaluation of investment efficiency, investment efficiency evaluation methods, models, criteria.

\section{Introduction}

Investments in real estate sector exist in all the life cycle stages of the economy. Micro- and macroenvironment determines the risk levels and complexity of projects realization. Generally investors - private individuals, corporations or investment funds - are solving the problem how to use current resources to gain the maximum benefits from the investments. Thus, each investor considers the problems of alternative projects selection, investment resources allocation, real estate value development, maintenance and enhancement. Different authors, analyzing investments and investments' assessment, propose various methods of investment projects evaluation. They can be categorized as financial, risk assessment, multiple criteria evaluation and other methods. Each of these methods has particular advantages and disadvantages; indeed the unified algorithm of investment evaluation is still not developed.

The main purpose of this article is to develop the improved algorithm for real estate investment projects ' efficiency evaluation. Basing on this algorithm, projects developers and valuators will be able to determine the efficiency of real estate investment projects in accordance to investor's needs and to set projects' priorities list basing on their efficiency level.

The selection of appropriate model and methods can solve the problem of risk and uncertainty management in investment decision-making. This will guide to correct real estate investment directions and will lead to higher real estate investments quality as well as to value enhancement.

\section{The algorithm for real estate projects' investment decisions evaluation}

Basing on the analyzed investment decisions evaluation methods, their advantages and disadvantages, the algorithm of real estate investment decisions evaluation was created (Fig. 1). On the basis of this algorithm, projects' developers and valuators can estimate the efficiency of the investment projects, investor's requirements satisfaction level as well as to set projects' efficiency priorities.

The proposed algorithm allows to make real estate investment projects' efficiency evaluation and to form 
their priorities list basing on the hierarchically-structured system of qualitative and quantitative evaluation criteria by using the complex multiple criteria risk and efficiency evaluation method.

Real estate projects' efficiency evaluation process consists of 7 main stages to be implemented by interested in efficiency evaluation and projects' comparison stakeholders groups (e.g. customers, developers, investors):

- Stage 1. Identification of investor's targets and purposes;

- Stage 2. Projects' selection (Initial projects' data gathering);

- Stage 3. Determination of projects' parameters;

- Stage 4. Analysis and comparison of the parameters;

- Stage 5. Multiple criteria evaluation of projects' efficiency;

- Stage 6. Conclusions and recommendations about projects' efficiency;

- Stage 7. Investment decision-making.

The presented evaluation model involves the whole cycle of investment decision-making - from the investor's targets and purposes identification to the final investment decision-making. The above mentioned stages are discussed further.
The initial stage is to identify investor's targets and restrictions. Investment is influenced by various factors: tax rates, inflation level and cash flow; and the main participants are: investors, hypothec suppliers, renters, government, final real estate users, etc.

In this stage primal ideas are also considered, and the ideas which obviously can not be realized or are unprofitable are eliminated. Initial ideas selection process is performed basing on the general criteria: preliminary price of the project (both economic and social), demand for the project's product, guarantees, risk, raw materials price, etc.

Each project usually has interrelated targets, outlining projects' structure, participants and their needs.

In order to estimate real estate project as a whole, the authors propose to make the detailed environmental analysis which may consist of several stages:

- Investment environment (business perspectives) analysis;

- Legal environment analysis;

- Object's techno-economic environment analysis (evaluation of attractiveness of the territory);

- Financing parameters calculations;

- Financial analysis;

- Risk analysis.

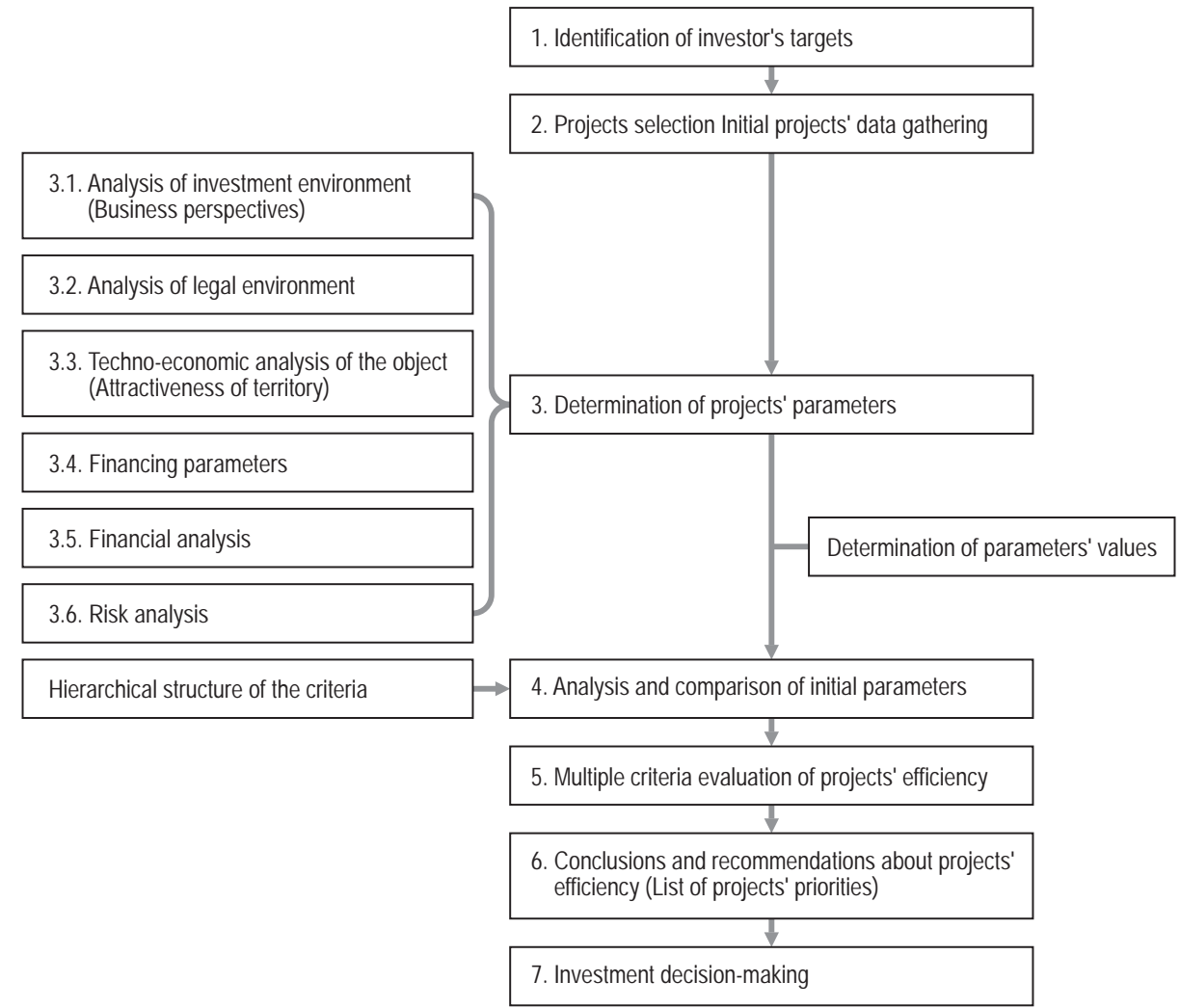

Fig. 1. Proposed algorithm for real estate investment decisions evaluation 
Real estate investment projects can be described as the complicated phenomena. When a phenomenon is getting complicated, acquiring more particular features or aspects, it is becoming more difficult to determine the relationships between the criteria describing it. In this case it is hardly possible to determine the criteria weights based on the expert evaluation. Moreover, the question arises if the statement that the criteria describing a complicated phenomenon are interrelated as a single system is true (Ginevičius, Podvezko 2003, 2006; Ginevičius 2007a, b).

Recently some more advanced multicriteria evaluation methods have been offered for determining the criteria weights. However, they cannot solve the problem caused by a large number of the criteria to be evaluated (Ginevičius, Podvezko 2003).

An effective solution would be to reduce the number of criteria. This may be achieved in two ways. The first approach is aimed at eliminating some criteria and retaining only key indicators in a set. However, the more criteria are eliminated, the less accurate is the description of the project. Therefore, this approach has limitations.

The other method is associated with grouping the criteria for further treatment. In this way criteria are transformed into structural sets of criteria, with the criteria presented at the first level and their groups provided at the second level - the hierarchically-structured system is formed (Ginevičius, Podvezko 2007).

It should be mentioned that hierarchical view in multiple criteria based evaluation theory and practice is rather new yet.

After the structure of criteria is formed and weights defined the next step is to perform the multiple criteria analysis of the real estate projects.

As the real estate projects deal with high risk and uncertainty for their analysis, authors propose to use the stochastic parameters instead of discreet ones. For this purpose Monte Carlo simulation method can be used.

After the criteria weights are determined and particular multiple criteria method selected, the parameters simulated, then the multiple criteria projects' analysis is performed aiming to rank real estate projects' priorities list basing on their efficiency. When the best project alternative is determined the next step is investment decision-making.

All the steps mentioned in the algorithm are performed basing on certain methodology and methods to be selected by user. The proposed methods for evaluation criteria structuring, weights determination, stochastic simulation and multiple criteria analysis are further discussed.

\section{Hierarchically-structured system of the criteria for real estate projects' efficiency evaluation}

Previously all the real estate projects evaluation criteria were analyzed together in effort to assess their relations at one level. It negatively influenced criteria weights determination objectivity as the complicated phenomenon (as real estate project is) can be evaluated basing on many interrelated criteria. The other approach was to eliminate some criteria and retain only key indicators in a set. Both of the approaches are not accurate enough. For this purpose more advanced methods should be used.

If the analyzed phenomenon is complicated enough, the main task is not to find the relations between all of the criteria but to group the criteria basing on particular characteristics (Ginevičius 2007a, b). In other words, complex phenomenon is divided into "spawns" (aspects) and related sets of criteria are formed. The significance and rationality of this method comes from considerations that as less criteria reflect some aspect of the analyzed phenomenon, so it digresses from the analyzed aspect essence as much it reflects the other aspect of phenomenon. If it is not close enough to any aspect of the analyzed phenomena, it means that it is an aspect by itself. Following this assumption, the system of criteria describing complicated phenomena is not at the single level and encourages hierarchically-structured criteria system development (Ginevičius 2007a, b; Podvezko 2008). This theory was applied for real estate projects' efficiency evaluation criteria selection and formalization.

Basing on the literature analysis (Belli et al. 1997; Brown, Matysiak 2000; Byrne 1996; Виленский et al. 2004; Бирман, Шмидт 1997; Максимов 2003; Шапиро et al. 1996; Lumby 1996 and others) the list of real estate projects' evaluation criteria was developed (see Table 1).

Basing on the list, projects' efficiency can be described by 43 criteria. It is obvious, however, that the abovementioned criteria have different influence on investment decisions as well as their types are different. In order to estimate their interrelations and weights adequately to phenomenon, the hierarchically-structured system of the criteria should be developed.

As the system of criteria was developed basing on literature analysis, it is theoretical and must be tested practically. For this purpose the survey of experts, consisting of real estate market valuation, banking sector 
Table 1. The list of real estate projects' economic efficiency evaluation criteria

\begin{tabular}{|c|c|c|c|}
\hline 1 & Net present value NPV & 23 & Mean of NPV \\
\hline 2 & Payback time of investments & 24 & Square deviation of NPV probabilistic distribution \\
\hline 3 & Internal rate of return IRR & 25 & Dispersion of NPV \\
\hline 4 & Modified internal rate of return & 26 & Diapason of NPV values with probabilistic 2sigma \\
\hline 5 & Investment efficiency coefficient & 27 & NPV standard \\
\hline 6 & Expected integral effect & 28 & Cash flow \\
\hline 7 & Profitability index & 29 & Liquidation value \\
\hline 8 & Business perspectives & 30 & Objects'balance value \\
\hline 9 & Initial investment & 31 & Capital price increase \\
\hline 10 & Extra investment & 32 & Dept refund time \\
\hline 11 & Number of work places & 33 & Investor's participation rate in general investment \\
\hline 12 & National taxes & 34 & Weighted average cost of capital (WACC) \\
\hline 13 & Social living level (index) & 35 & Legal environment \\
\hline 14 & Attractiveness of the territory & 36 & Distance to business center \\
\hline 15 & Net incomes & 37 & Population with lower than average incomes \\
\hline 16 & Calculated profit & 38 & Pedestrian and transport flows \\
\hline 17 & Gross income multiplier & 39 & Distance to water resources \\
\hline 18 & Overall capitalization rate & 40 & Intensity of work places in area \\
\hline 19 & Equity dividend rate & 41 & Distance to park \\
\hline 20 & Own resources demand & 42 & Criminality \\
\hline 21 & Discount rate & 43 & Competition \\
\hline 22 & Minimal and maximal values of $\mathrm{d}$ & & \\
\hline
\end{tabular}

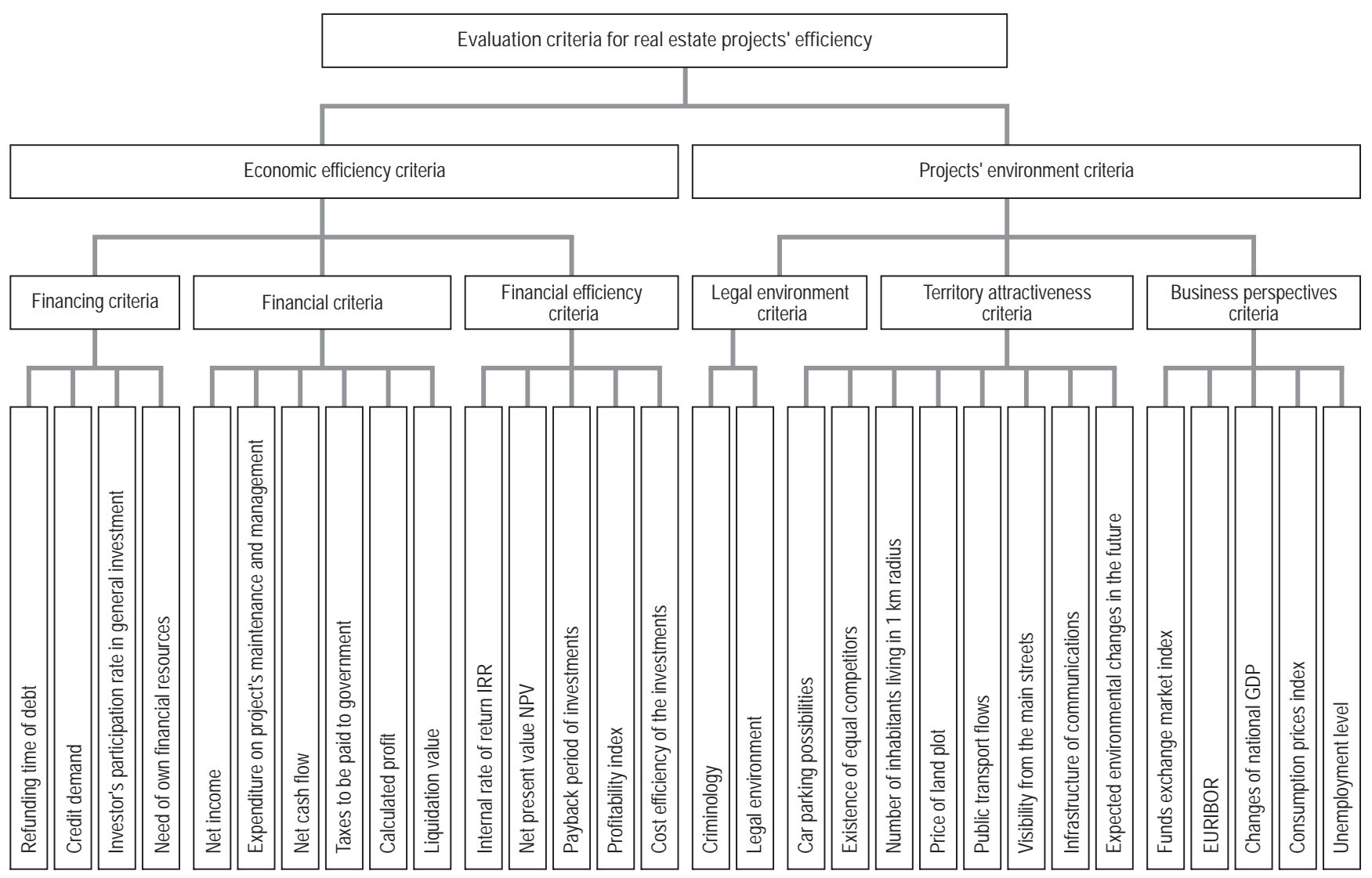

Fig. 2. Hierarchically-structured system of the criteria for real estate projects' efficiency valuation 
specialists, private investors, and risk valuation specialists was implemented. The main tasks were:

- To discover if the theoretically-based criteria system is comprehensive enough; if all the mentioned criteria are significant (if it is rational to calculate them), and to add some criteria to the system which are used by practitioners;

- To determine weights of criteria and weights of their groups.

- Basing on these assumptions and survey results, the hierarchically-structured system of real estate investment projects' efficiency evaluation criteria was developed (Fig. 2).

\section{Determination of criteria weights of real estate projects' investment decisions evaluation}

Irrespective of selected multiple criteria method for problem solving, the initial step is to determine weights of the criteria which reflect criteria significance on project's efficiency. Criteria weights calculation was widely discussed in the scientific literature (Podvezko 2008; Ginevičius 2007a; Hwan, Yoon 1981; Zavadskas et al. 1995; Ustinovičius et al. 2005; Ustinovičius, Stasiulionis 2001; Saaty 1980, 2005 and many others). In different authors' works applied criteria weights calculations can be categorized into objective and subjective (Podvezko 2006, 2008). The weights can be calculated basing on various mathematical programming models.

Indeed, weights can be calculated by various methods, in any case, the expert estimates are usually considered (Podvezko 2006) - subjective method is applied. In real estate projects' evaluation the expert method is the most suitable because projects' efficiency decisions are influenced by subjective targets of the investors. For these purposes, in practice the ranking method is usually chosen.

Basing on this method the weights of criteria are determined directly. For example, criteria weights can be determined by 10 scale scores from 1 to 10 .

To determine the degree of agreement between the expert estimates, the Kendall (1970) concordance coefficient $W$ is used:

$$
\bar{W}=\frac{12 S}{r^{2}\left(n^{3}-n\right)-r \sum_{k=1}^{r} T_{k}},
$$

where $S$ - the sum of each of the criteria deviation squares:

$$
\begin{gathered}
S=\sum_{j=1}^{n}\left[\sum_{k=1}^{r} t_{j k}-\frac{1}{n} \sum_{j=1}^{n} \sum_{k=1}^{r} t_{j k}\right]^{2}, \\
T_{k}=\sum_{l=1}^{H_{1}}\left(h_{l}^{3}-h_{l}\right),
\end{gathered}
$$

where $T_{k}$ - rate of interrelated ranks of $k$ ranking; $H_{l}-$ number of equal rank groups $k$; equal ranks number in $l$ group determined by expert $h_{l} ; t_{j k}-$ rank of $k$ experts for $j$ criteria; $r$ - number of experts; $n$ - number of efficiency criteria.

If there are no interrelated ranks, concordance coefficients are determined by equation:

$$
\bar{W}=\frac{12 S}{r^{2}\left(n^{3}-n\right)} \text {. }
$$

Concordance coefficient is equal to 1 if the rankings of all the experts are the same, and equal to 0 if all the rankings are different, e.g. not matching at all.

The concordance coefficient calculated basing on equations 3 and 4 has the random number. In order to determine the concordance it is needed to know experts number $r$ and distribution frequency of $n$ comparative objects:

$$
\chi^{2}=\frac{12 S}{r n(n+1)-\frac{1}{n-1} \sum_{k=1}^{r} T_{k}} .
$$

According to the accepted significance level $\alpha$, the critical value of $\chi_{k r}^{2}$ is taken from the table of $\chi^{2}$ distribution with degrees of freedom. If the value of $\chi^{2}$ calculated by formula (5) is larger than $\chi_{k r}^{2}$, the estimates of the experts are assumed to be in agreement. In other case, if $\chi^{2}<\chi_{k r}^{2}$ experts are not in agreement, their opinions are substantially different. This problem can be solved by increasing the number of experts.

The discussed method was practically used for weights determination of investment projects' evaluation criteria. Results are shown in Table 2.

Table 2 shows the hierarchically- structured real estate projects' evaluation criteria, their groups and subgroups as well as weights of criteria. 
Table 2. Weights of real estate projects' evaluation criteria

\begin{tabular}{|c|c|c|c|c|c|c|}
\hline \multirow{31}{*}{ 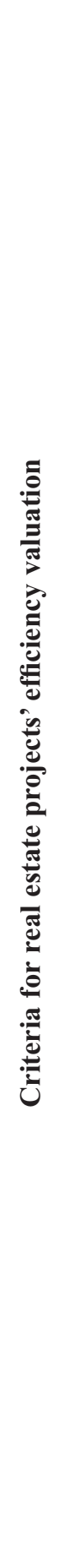 } & Group & Weight & Criteria & Weight & Criteria & Weight \\
\hline & \multirow{15}{*}{ 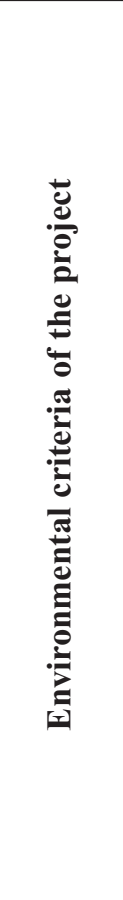 } & \multirow{15}{*}{0.4} & \multirow{5}{*}{$\begin{array}{l}\text { Criteria } \\
\text { determining } \\
\text { business } \\
\text { perspectives }\end{array}$} & \multirow{5}{*}{0.35} & Funds exchange market index & 0.16 \\
\hline & & & & & EURIBOR & 0.31 \\
\hline & & & & & Changes in national GDP & 0.17 \\
\hline & & & & & Consumption prices index & 0.25 \\
\hline & & & & & Unemployment level & 0.10 \\
\hline & & & \multirow{8}{*}{$\begin{array}{l}\text { Territory } \\
\text { attractiveness } \\
\text { criteria (depend } \\
\text { on project type) }\end{array}$} & \multirow{8}{*}{0.325} & Car parking possibilities & 0.19 \\
\hline & & & & & Existence of equal competitors & 0.12 \\
\hline & & & & & Number of habitants living in $1 \mathrm{~km}$ radius & 0.12 \\
\hline & & & & & Price of land plot & 0.12 \\
\hline & & & & & Public transport flows & 0.10 \\
\hline & & & & & Visibility from the main streets & 0.20 \\
\hline & & & & & Infrastructure of communications & 0.06 \\
\hline & & & & & Expected environmental changes in the future & 0.09 \\
\hline & & & \multirow{2}{*}{$\begin{array}{l}\text { Criteria } \\
\text { determining } \\
\text { legal environment }\end{array}$} & \multirow{2}{*}{0.325} & Criminology & 0.27 \\
\hline & & & & & Legal environment & 0.73 \\
\hline & \multirow{15}{*}{ 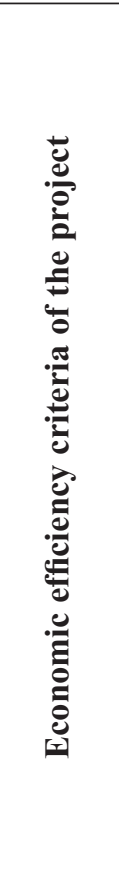 } & \multirow{15}{*}{0.6} & \multirow{5}{*}{$\begin{array}{l}\text { Financial } \\
\text { efficiency } \\
\text { criteria }\end{array}$} & \multirow{5}{*}{0.4} & Internal rate of return IRR & 0.25 \\
\hline & & & & & Net present value NPV & 0.16 \\
\hline & & & & & Pay-back period of investments & 0.46 \\
\hline & & & & & Profitability index & 0.07 \\
\hline & & & & & Cost efficiency of investments & 0.06 \\
\hline & & & \multirow{6}{*}{$\begin{array}{l}\text { Financial } \\
\text { criteria }\end{array}$} & \multirow{6}{*}{0.2} & Net incomes & 0.38 \\
\hline & & & & & $\begin{array}{l}\text { Expenditure on project maintenance and } \\
\text { management }\end{array}$ & 0.25 \\
\hline & & & & & Net cash flow & 0.07 \\
\hline & & & & & Taxes to government & 0.15 \\
\hline & & & & & Cumulative profit & 0.07 \\
\hline & & & & & Liquidation value & 0.08 \\
\hline & & & \multirow{4}{*}{$\begin{array}{l}\text { Financing } \\
\text { criteria }\end{array}$} & \multirow{4}{*}{0.4} & Demand for own resources & 0.32 \\
\hline & & & & & Investor's participation rate in general investment & 0.18 \\
\hline & & & & & Credit demand & 0.23 \\
\hline & & & & & Time of debt refund & 0.28 \\
\hline
\end{tabular}

\section{Stochastic modelling of real estate projects' evaluation parameters}

The problem of uncertainty, particular to investment projects and their parameters, influences additive risks (Rutkauskas 2000, 2001a, b; Rutkauskas, Tamošiūnienè 2002). A probabilistic nature of the considered phenomena may be dealt with by statistical simulation, allowing us to determine the variation intervals.
For parameters which are calculated from forecasted cash flow, Monte Carlo simulation method can be used and statistical simulation of discount rate performed. Basing on this dimension the simulation of other related parameters can be implemented.

Statistical simulation of one parameter related to other parameters allows determining maximally right distributions and to keep the interrelations of parameters sustained. 
In this case the considered phenomena, or their component values changing while repeating many times, and random although possible result for each variant are calculated. If model's stochastic parameter (characteristic) $X$ is evaluated by experts or the massive amount of statistical data exists, it is possible to determine the probabilistic distribution of the function $F(X)$ with the accepted significance level, close to 1 , and to calculate variation interval limits for each parameter.

As a result, the estimates of the criteria provided by multicriteria evaluation methods are expressed in terms of the intervals of their possible variations rather than as discrete quantities. This makes it possible to check the consistency of ranging the alternatives, thereby reducing risks in multicriteria decision-making.

Statistical simulation is based on contingent or pseudocontingent numbers $\xi_{1}, \xi_{2}, \ldots, \xi_{N}$ gradually distributed in the interval $[0,1]$, generated sequence, where $N-$ number of simulations (Podvezko 2008).

Statistical simulation can be applied to any of $X$ parameters. It may be practically implemented as follows:

1 . The random variables $\xi_{i}$ gradually distributed in the interval $[0,1]$ are generated by computer, where $i=$ $1, \ldots, N, N$ - number of simulations.

2. If the type of theoretical distribution of a random quantity $X$ with the distribution function $\mathrm{F}(X)$ is normal (Gauss), then its random variable is found from the equation:

$$
\xi_{i}=F\left(X_{i}\right) \text { or } X_{i}=F^{-1}\left(\xi_{i}\right),
$$

where $F^{-1}\left(\xi_{i}\right)$ is the reciprocal expression of function $\mathrm{F}(X)$.

Random values are simulated for all the multiple criteria method parameters basing on equation (6). All the synthetic values of the parameters are inserted into equation of multiple criteria model parameters and values of parameters $X_{1}^{(i)}, X_{2}^{(i)}, \ldots, X_{n}^{(i)}$ are calculated and the priority set of the comparable objects is determined (where $i$-number of the particular simulation; $I=1$, $2, \ldots, N ; N$ - total number of simulations.

3. After all the $N$ simulations are performed, the range of limits for each object's priority is determined.

If the random variable (as it usually is in practice) is distributed according to the normal probabilistic distribution with parameters $\alpha$ and $\sigma$, then random quantity $X$ can be simulated basing on this equation:

$$
X=\alpha+\sigma \frac{\sum_{i=1}^{k} \xi_{i}-\frac{k}{2}}{\sqrt{\frac{k}{12}}},
$$

where $\xi_{i}$ - random variables gradually distributed in the interval $[0,1], i=1, \ldots, k, k$ - number of simulated values. In practice it is convenient to use equation (7) when $k=12-$ a set of 12 simulated random numbers gradually distributed in the interval $[0,1]$ exists, the single normal distribution value is obtained. In this case variable $X$ can be calculated by the equation:

$$
X=\alpha+\sigma\left(\sum_{i=1}^{12} \xi_{i}-6\right) \text {. }
$$

\section{Selection of multiple criteria method for real estate projects' investment decision-making}

The decision-making theory helps to make decisions basing on some or many conflicting criteria. The selectonovation problems arise in various fields, indeed all the tasks have the same general characteristics (Hwang, Yoon 1981; Zavadskas et al. 1995): problems have some indicators, evaluation criteria are conflicting, and valuation criteria have different measuring units. The result of these problems solution - the best alternative developed or chosen from the set of given alternatives.

In order to select the most appropriate method for multiple criteria evaluation of real estate projects' efficiency, some of the multiple criteria evaluation methods were considered and compared: SAW, ELECTRE III, TOPSIS, COPRAS, MCDM-23 (Table 3). Analysis of the mentioned methods revealed that they differ by complexity and the best alternative selection approach. For these reasons the analysis results may vary.

In SAW and MCDM-23 methods the ideal alternative is determined by simple additive weighting.

ELECTRE III, TOPSIS, COPRAS methods allow to determine the intervals of criteria values.

Basing on comparison analysis results it can be stated that for investment projects evaluation with particular risks, the methods allowing to determine the range limits of values variation are more suitable. These are ELECTRE III, TOPSIS and COPRAS.

TOPSIS method is based on vectoral evaluation. Normalization of values is strongly dependent on valuation accuracy, for this reason the ability to select the best alternative in risk conditions is restricted. For this purpose this method is less suitable for real estate projects' evaluation.

COPRAS method assumes direct and proportional dependence of significance and priority of investigated 
Table 3. Comparison of multiple criteria evaluation methods

\begin{tabular}{|c|c|c|c|c|c|}
\hline Method & $\begin{array}{c}\text { Requirements to } \\
\text { criteria }\end{array}$ & $\begin{array}{c}\text { Matrix of } \\
\text { normalization }\end{array}$ & $\begin{array}{l}\text { The way of } \\
\text { best alternative } \\
\text { selection }\end{array}$ & $\begin{array}{c}\text { Possibility } \\
\text { to evaluate } \\
\text { boundaries of } \\
\text { values oscillation }\end{array}$ & Complexity \\
\hline SAW & Numeric values & $\begin{array}{l}\text { Weight according to } \\
\text { maximal and minimal } \\
\text { values }\end{array}$ & Weighting & No & Very simple \\
\hline ELECTRE III & $\begin{array}{c}\text { Qualitative and } \\
\text { quantitative values }\end{array}$ & $\begin{array}{l}\text { Not performed, only } \\
\text { oscillation limits } \\
\text { determined }\end{array}$ & $\begin{array}{l}\text { Comparative } \\
\text { ranking }\end{array}$ & Yes & Complicated \\
\hline TOPSIS & $\begin{array}{c}\text { Qualitative and } \\
\text { quantitative values }\end{array}$ & Vectoral & Vectoral & No & Very simple \\
\hline COPRAS & $\begin{array}{c}\text { Qualitative and } \\
\text { quantitative values }\end{array}$ & $\begin{array}{l}\text { Proportional basing on } \\
\text { other criteria }\end{array}$ & Proportional & Yes & Simple \\
\hline MCDM-23 & $\begin{array}{c}\text { Qualitative and } \\
\text { quantitative values }\end{array}$ & Scoring & Weighting & No & Very simple \\
\hline
\end{tabular}

versions on a system of criteria adequately describing the alternatives and on values and significances of the criteria. Best alternative is selected according to all the criteria set estimations, indeed there is no possibility to perform pair comparison of the alternatives.

Basing on the aforementioned disadvantages the authors propose to use ELECTRE III method for real estate projects' efficiency evaluation. This method suites best for investment projects' efficiency evaluation purposes because it uses the rule of majority in an outranking relation. The outranking relations are built on two indices, namely the concordance index and the discordance index. Based on them, an alternative is "at least as good as" another, if a sufficient majority of criteria support this appraisal (concordance principle) and the opposition of the minority of criteria is not strong enough to prevent it (discordance principle). Basing on ELECTRE III the best chosen project alternative satisfies not only the economic needs but also social needs. Furthermore, this method allows evaluating range limits of various characteristics (including risk factors) variation.

The use of the ELECTRE family methods for ranking and classification problems, present the following advantages (Buchanan, Sheppard 2007):

- Potential use of both quantitative and / or qualitative criteria.

- Acceptance and integration of the concept of noncomparability of alternatives in the whole procedure of classification or ranking.

- Treatment of non-comparability, with two approxi- mations, so as to focus on the alternatives that exhibit special characteristics.

- Simplicity of comparisons and consequentially understanding of the results.

- Convenience in the application of the method, manually or with a personal computer.

- Ranking of the projects is structured.

- It is possible to determine alternatives basing on stakeholders needs.

ELECTRE (Elimination et Choice Translating Reality) was conceived by Bernard Roy in response to deficiencies of existing decision-making solution methods. ELECTRE is more than just a solution method; it is a philosophy of decision aid. However, for this paper we shall concentrate on the method and specifically on what is referred to as ELECTRE III. ELECTRE has evolved through a number of versions (I through IV); all are based on the same fundamental concepts but are operationally somewhat different. The principles of the method application are further discussed (Roy 1991).

Step 1. The numeric range limits of the parameters are set: 1) irrelevant variation limit $\left.q_{j}(a), 2\right)$ appropriative variation limit $p j(a)$; not appropriative variation limit (Veto) threshold $v_{j}(a)$.

Step 2. The variants are compared basing on all the criteria, i.e. the comparison of alternatives leads to the building for each pair of alternatives $(a, b)$ of a concordance index, that is expressed as:

$$
\begin{aligned}
& g_{j}(b)=g_{j}(a)+p_{j}\left[g_{j}(a)\right] \rightarrow c_{j}(a, b)=0 \\
& c_{j}(b, a)=1 ;
\end{aligned}
$$




$$
\begin{aligned}
& g_{j}(a)+q_{j}\left[g_{j}(a)\right]<g_{j}(b) \leq g_{j}(a)+p_{j}\left[g_{j}(a)\right] \\
& 0<c_{j}(a, b) \leq 1 ; c_{j}(b, a)=1 .
\end{aligned}
$$

By interpolation method each value of criteria matrix $c_{j}(a, b)$ is calculated:

$$
\begin{gathered}
c_{j}(a, b)=\frac{p_{j}\left[g_{j}(a)\right]-\left[g_{j}(b)-g_{j}(a)\right]}{p_{j}\left[g_{j}(a)\right]-q_{j}\left[g_{j}(a)\right]}, \\
g_{j}(a) \leq g_{j}(b) \leq g_{j}(a)+q_{j}\left[g_{j}(a)\right] \rightarrow c_{j}(b, a)=1,
\end{gathered}
$$

where $g_{j}(a)$ - comparative criteria $j$ of variant $a ; g_{j}(b)-$ substantive criteria $j$ of $b$ variant.

Step 3. All the indices of an alternative are added, giving its total concordance index $C(a, b)$ for the term "alternative a is at least as good as alternative b, regarding the whole set of criteria" as:

$$
C(a, b)=\frac{\sum_{j=1}^{m} k_{j} \times c_{j}(a, b)}{\sum_{j=1}^{m} k_{j}},
$$

where $k_{j}$ is the weight of criteria $j$.

Step 4. The discordance index $\mathrm{D}_{j}(a, b)$ expresses the opposition to the term "alternative a is at least as good as alternative $b$, regarding criterion $j$ " and is estimated by:

$$
\begin{aligned}
& g_{j}(b)-g_{j}(a) \leq p_{j}\left[g_{j}(a)\right] \\
& D_{j}(a, b)=0, \\
& p_{j}\left[g_{j}(a)\right]<g_{j}(b)-g_{j}(a)<v_{j}\left[g_{j}(a)\right] \\
& 0<D_{j}(a, b) \leq 1 .
\end{aligned}
$$

The discordance values of matrix $D_{j}(a, b)$ are calculated:

$$
D_{j}(a, b)=\frac{g_{j}(b)-g_{j}(a)-p_{j}\left[g_{j}(a)\right]}{v_{j}\left[g_{j}(a)\right]-p_{j}\left[g_{j}(a)\right]} ;
$$

$g_{j}(b)-g_{j}(a) \leq v_{j}\left[g_{j}(a)\right] ; D_{j}(a, b)=1$, where $\mathrm{vj}$

is the veto threshold.

Step 5. The discordance index $D_{j}(a, b)$ expresses the opposition to the term "alternative a is at least as good as alternative $\mathrm{b}$, regarding criterion $j$ " and is estimated by:

if $D(a, b)>C(a, b)$, then $d(a, b)=0$;

if $D(a, b)=C(a, b)$, then $d(a, b)=C(a, b)$; if $D_{j}(a, b) \geq C_{j}(a, b)$, then

$$
d_{j}(a, b)=C_{j}(a, b) \times \frac{1-D_{j}(a, b)}{1-C_{j}(a, b)} .
$$

Step 6. Basing on the results the list of priorities is developed.

The ranking algorithm of ELECTRE III uses the credibility matrix (i.e. the matrix of $\sigma s(a, b)$ ) to build two rankings using descending and ascending distillation: descending distillation selects at first the best alternatives to end the process with the worst ones. On the contrary, the ascending distillation first selects the worst alternatives to end the process with the best ones. Two complete preorders are therefore found for all the alternatives. An alternative which is incomparable to a group of others will be positioned at the end of this group in the descending distillation and at the top in the ascending distillation.

Manual application of this method is quite complicated. In order to solve this problem, computerized calculations are usually used.

\section{Conclusions}

1. The original real estate investment decisionmaking model was created with particular emphasis on projects' risk. Model allows analyzing investment projects in a complex way, considering needs of participating stakeholders groups as well as macro and microenvironment factors.

2. The algorithm of investment decision-making stages is developed and methodology designed.

3. The hierarchically-structured system of projects' efficiency evaluation criteria was developed. The system allows describing investment projects characteristics in the objective and structured way, basing on weights of criteria and their groups.

4. The developed real estate projects' efficiency evaluation model is based on risk assessment. The risk assessment is performed by simulation, modelling and determination of values in a stochastic manner. The methods for stochastic valuation were selected and discussed.

5. Various methods of multiple criteria based decision-making were analyzed, advantages and disadvantages outlined and compared. The best method for real estate projects' efficiency evaluation is concluded to be ELECTRE III which uses the rule of majority in the outranking relation. 


\section{References}

Belli, P.; Anderson, J.; Barnum, H.; Dixon, J.; Tan, J. P. 1997. Handbook on Economic Analysis of Investment Operations. Learning and Leadership Center. 159 p.

Brown, R. G.; Matysiak, G. A. 2000. Real Estate Investment. London: Prentice Hall. 707 p.

Buchanan, J.; Sheppard, Ph. 2007. Ranking Projects Using the ELECTRE Method. The Pennsylvania State University. 9 p.

Byrne, P. 1996. Risk, Uncertainty and Decision Making in Property Development. Second Edition. E \& FN Spon, an imprint of Chapman \& Hall, 2-6 Boundary. London. 162 p.

Ginevičius, R. 2007a. Procesų ir reiškinių hierarchinis struktūrizavimas [Hierarchical structuring of processes and phenomena], Verslas: teorija ir praktika [Business: Theory and Practice] 8(1): 14-18.

Ginevičius, R. 2007b. Sudètingo reiškinio struktūrizuotos rodiklių sistemos formavimas [Generating a structured system of criteria for describing a complicated phenomenon], Verslas: teorija ir praktika [Business: Theory and Practice] 8(2): 68-72.

Ginevičius, R.; Podvezko, V. 2007. Some problems of evaluating multicriteria decision methods, International Journal of Management and Decision Making 8(5/6): 527-539. doi:10.1504/IJMDM.2007.013415

Ginevičius, R.; Podvezko, V. 2003. Hierarchiškai struktūrizuotų rodiklių reikšmingumo kompleksinis vertinimas [Complex evaluation of hierarchically-structured criteria weights], Verslas: teorija ir praktika [Business: Theory and Practice] 4(3): 111-116.

Ginevičius, R.; Podvezko, V. 2006. Hierarchinių struktūrų formavimas taikant jų elementų tranzityvumą [Development of hierarchical structures based on their elements transitivity], Verslas: teorija ir praktika [Business: Theory and Practice] 5(3): 85-89.

Hwang, C. L.; Yoon, K. 1981. Multiple (Attribute) Decision Making. Methods and Applications. Berlin-HeidelbergNew York. 259 p.

Kendall, M. 1970. Rank Correlation Methods. Griffin, London.

Lumby, S. 1996. Investment Appraisal and Financial Decisions. London: Chapman \& Hall. 667 p.

Podvezko, V. 2006. Neapibrěžtumo įtaka daugiakriteriniams vertinimams [Multicriteria evaluation under uncertainty], Verslas: teorija ir praktika [Business: Theory and Practice] 7(2): 81-88.

Podvezko, V. 2008. Sudètingų dydžių kompleksinis vertinimas [Comprehensive evaluation of complex quantities], Verslas: teorija ir praktika [Business: Theory and Practice] 9(3): 160-168. doi: 10.3846/1648-0627.2008.9.160-168
Roy, B. 1991. The outranking approach and the foundation of ELECTRE methods, Theory and Decision 31: 49-73. doi:10.1007/BF00134132

Rutkauskas, A. V. 2000. Formation of adequate investment portfolio for stochasticity of profit possibilities, Property Management 4(2): 100-115.

Rutkauskas, A. V. 2001a. Financial analysis problems under presence of uncertainty, Property Management 5(1): 45-62.

Rutkauskas, A. V. 2001b. Nekilnojamojo turto plètoté, investicijos ir rizika [Real estate development, investments and risk]. Vilnius: Technika. 404 p.

Rutkauskas, A. V.; Tamošiūnienè, R. 2002. Verslo projektavimas [Business project]. Vilnius: Technika. 240 p.

Saaty, T. L. 1980. The Analytic Hierarchy Process. M. GrawHill, New York.

Saaty, T. L. 2005. The analytic hierarchy and analytic network processes for the measurement of intangible criteria and for decision-making, in Multiple Criteria Decision Analysis: State of the Art Surveys. Ed. by J. Figueira; S. Greko; M. Ehrgott. Springer, 345-408.

Ustinovičius, L.; Stasiulionis, A. 2001. Komercinių objektų statybos vietos parinkimo vertinimas įvairiais aspektais [Multicriteria-based estimation of selection of commercial property construction site], Statyba [Civil Engineering] 7(6): 474-480.

Ustinovičius, L.; Andruškevičius, A.; Kutut, V.; Balcevič, R.; Barvydas, A. 2005. Inžinerinių ir statybos projektavimo sprendimų verbalinè analizė [Verbal analysis of engineering and constructional solutions], Technological and Economic Development of Economy 11(3): 220-231.

Zavadskas, E.; Kaplinski, O.; Kaklauskas, A.; Brzezinski, J. 1995. Expert Systems in Construction. Trends, Potential \& Applications. Vilnius: Technika. 180 p.

Бирман, Г.; Шмидт, С. 1997. Экономический анализ инвестиичионных проектов [Birman, G.; Shmidt, S. Economic analysis of investment projects]. Пер. с англ. Под ред. Л. Белых. Москва: Банки и биржи; ЮНИТИ. 631 с.

Виленский, П. Л.; Лившиц, В. Н.; Смоляк, С. А. 2004. Оиенка эффективности инвестиционных проектов [Vilenskij, P. L. et al. Evaluation of investment projects efficiency]. Москва: Дело. 888 с.

Максимов, С. Н. 2003. Девелопмент, развитие недвижимости, организация, управление, финансирование [Maksimov, S. N. Development, management and financing of organizational property]. С.-Петербург: Питер. 256c.

Шапиро, В. Д.; Ильин, Н. И.; Лукманова, И. Г.; Немчин, А. М.; Петрова, С. Н.; Романова, К. Г. 1996. Управление проектами [Shapiro, V. D. et al. Project management]. Москва. 610 с. 